Cook, Sir Reginald Stradling, Sir Jonathan Davidson, Sir Roger Hetherington ; Other Members of Council, Mr. H. E. Aldington, Sir Stanley Angwin, Mr. D. B. Brow (India), Mr. W. S. Cameron, Mr. F. M. Corkill (New Zealand), Dr. W. H. Glanville, Mr. A. Gray (Canada), Mr. G. L. Groves, Mr. H. Hamer, Dr. E. J. Hamlin (South Africa), Mr. A. C. Hartley, Mr. G. H. Humphreys, Mr. L. Leighton, Mr. M. G. J. McHaffie, Mr. M. S. Moore (Australia), Mr. W. H. Morgan, Dr. H. J. Nichols (India), Mr. C. M. Norrie, Sir Leonard Pearce, Prof. A. J. S. Pippard, Mr. V. A. M. Robertson, Mr. W. P. Shepherd-Barron, Mr. W. K. Wallace, Mr. D. M. Watson, Sir Arthur Whitaker ; Past-Presidents, Sir John Thornycroft, Dr. David Anderson, Mr. F. E. Wentworth-Sheilds, Sir Peirson Frank; Secretary, Mr. E. Graham Clark.

\section{Curare in Anæsthesia}

THE Anæsthetics Committee, jointly appointed by the Medical Besearch Council and the Royal Society of Medicing, is considering the standardization of curare. Xhere are on the market at present two preparations for use in anæsthesia, one amorphous and gne crystalline, but both depend for their activity on d-tubocurarine chloride; the co-existence of peparations of different potency is a source of danger and may result in serious aecidents. The amorphous preparation, "Intocostrin", has, in fact, about onequarter the activity of the pure crystalline material. There is also some evidence of wide differences in the reactions of the patient, depending to some extent on the state of health of the individual at the time. The Committee, therefore, considers it advisable, in the present state of knowledge, to base the dose on the individual reaction to an initial small injection rather than on any dose/weight ratio. In the average healthy adult this initial dose could be 10-15 mgm. of crystalline $d$-tubocurarine chloride or 40-60 mgm. of "Intocostrin". In one otherwise healthy man with a recent perforated gas iric ulcer, so little as $5 \mathrm{mgm}$. of the crystalline material produced adequate muscular relaxation, and $15 \mathrm{mgm}$. would probably have been a considerable overdose.

The Anæsthetics Committee has been reconstituted with the following membership: Dr. C. F. Hadfield (chairman), Prof. F. H. Bentley, Dr. C. Langton Hewer, Mr. R. Vaughan Hudson, Dr. H. King, Prof. R. R. Macintosh, Dr. F. C. MacIntosh, Dr. M. D. Noswopthy and Dr. G. S. W. Organe (secretary). 316

Museums and the Deyingment of Visual Education A BRIEF reportar a paper entitled "Museums and General Edu?tid.", read by Mrs. Jacquetta Hawkes (Ministry f IEducation) on the occasion of the Mugums Afsociation Conference last July, appears in AMLuseums Journal of October 1946, p. 118. Mr Hawkes said that at the present time there is in the educational world a great vogue for the use of visual teaching methods. Unfortunately, visual education often means films mainly intended for factual instruction. Museums are uniquely qualified for visual education, because they can offer real things that can be handled. Mrs. Hawkes went on to suggest that museums should design exhibits to give intellectual instruction, offering objects without comment. By this encouragement of the intuitive sense and training in the judgment of individual quality, Mrs. Hawkes believes that museums can make their most valuable and distinctive contribution to the gontent of education. If her words reflect the attitude of the Ministry of Education, they form a happy augury for the improvement of the museum services of Britain, and it is highly important that this interest should be further explored by leading museum authorities.

\section{Jubilee of the Discovery of the Electron}

THE fiftiethanniversary of the discovery of the electron by sir J. J. Thomson will occur next year. To mark this jubilee and to demonstrate the tremendoxs influence such an advance in pure physics may have on the life of the community, the Physical Soliety and the Institute of Physics are jointly arranging a series of meetings and other functions to take place during September 25 and 26,1947 , in London. A special exhibition, which will remain open to the public for several weeks, will be held at the Science Museum, South Kensington, and will show the development of a vast range of modern indus. trial equipment from its earliest experimental origins.

\section{Announcements}

THE eleventh Liversidge Lecture of the Chemical Society wit be delivered by Prof. Harold C. Urey, of the Mnstitute of Nuclear Studies, University of Chicgro, at the Royal Institution, London, W.I, on December 18 at 7.30 p.m. He will speak on "Some Problems in the Separation of Isotopes".

Sir Alexander Fleming has been awarded the honoray gold medal of the Royal College of Surgeons in appreciation of his distinguished work and partiodlarly in recognition of his discovery of penicillin.

Mr. Kranneth Carter has been appointed secretary of the Therapeutic Research Corporation of Gregh Britain, Ltd., in succession to Dr. Frank Hartley.

Tне Canaridge Philosophical Society announces that the adjudicators for the Hopkins Prize have made the following awards for the period 1933-39: to Prof. J. D. Cockeroft, director of the Atomic Lnergy Research and Development Establishment at Harwell, for researches on the artificial transmutation of elements; and to Prof. E. A. Milne, Rouse Ball professor of mathematics in the University of Oxford, for researches on stellar structure and cosmology.

Prof. W. Hartridge, professor of physiology at St. Bay holomew's Hospital Medical College, University ff London, will deliver the Christmas Lectures "adapted to a Juvenile Auditory" at the Royal Institution on December 28, 31, January 2, 4, 7 and 9 ; he will speak on "Colours and How We See Them".

Mr. N J. Scongre, reader, in the Department of AnimalHusbandry at the Royal Veterinary College, has oen appointed to the Courtauld chair of animal husbandry, veterinary hygiene and dietetics in the College in succession to Prof. W. C. Miller, who resigned the chair in order to take up an appointment as director of the Equine Research Station of the Veterinary Educational Trust.

Dr. W/ L. Waterhouse, reader in the Faculty of Agricynture of the University of Sydney, has been appointed research professor in agriculture in recognition of his work in cereal pathology. 